\title{
IRON, LIEBIG'S LAW, AND THE GREENHOUSE
}

\author{
By John H. Martin
}

"... growth of a plant

is dependent on the

amount of food stuff

which is presented to it

in minimum quantity."

$$
\mathrm{B}_{\mathrm{A}}
$$
ARON JUSTIS VON LIEBIG (1803-1873), the founder of modern organic chemistry, is also recognized as the father of agricultural chemistry. He was the first to determine the exact elements taken up by plants from the air and soil, and this enabled him to develop efficient fertilizers. He raised the fundamental operations of agriculture to the level of an exact science (Moulton, 1942). With this knowledge, Liebig was the first to realize that the ". . . growth of a plant is dependent on the amount of food stuff which is presented to it in minimum quantity." This has become known in ecological circles as Liebig's Law of the Minimum (Odum, 1971).

\section{Liebig's Law and the Ocean}

Absence of fixed $\mathrm{N}$ is usually thought to be the factor limiting plant growth in the ocean as exemplified by the large oligotrophic gyres where little, if any, nitrate is present. However, in other large ocean areas, such as the Gulf of Alaska, the equatorial Pacific, and the southern ocean, $\mathrm{NO}_{3}$ and other major plant nutrients are readily available (Fig. 1). Clearly, factors other than major nutrient deficiency limit phytoplankton growth in these regions. However, what these factors are remains a subject of debate to this day.

Possibly the oldest explanation for the use or non-use of the major nutrients involves iron abundance. For example, in early Antarctic studies, Hart (1934) noted: "Among the . . . chemical constituents of sea water... possibly limiting phytoplankton production, iron may be mentioned . . . it may help to explain the observed richness of the neritic plankton . . . the land being regarded as a source of iron . . ." And in 1942 Hart said that: "Only where these (neritic) influences are felt do the Antarctic seas retain their claim to be amongst the richest in the world." Little changed in the next half century; i.e., in a recent review El-Sayed (1988) notes the very high productivity rates in Antarctic nearshore waters and states that such high rates ". . . have no doubt perpetuated the belief in the proverbial richness of the Antarctic waters."

J.H. Martin, Moss Landing Marine Laboratories, Moss Landing, CA, 95039, USA.
Critical evaluation should be easy for Hart's speculation on iron abundance by comparing nearshore versus offshore concentrations. And accordingly, dissolved and particulate iron levels were measured in many studies during the mid1900 s in various parts of the world's oceans. The general conclusion was that plenty of Fe was available for phytoplankton growth and that this element was not limiting. Similar conclusions were reached from enrichment experiments in which growth rates with and without $\mathrm{Fe}$ were compared.

However, during the 1970 s, a scientist studying lead at the California Institute of Technology began telling trace-element chemists that their numbers were wrong because they consistently contaminated their samples not only with lead but also with other trace elements. Dr. Clair Patterson thus began his successful crusade that led to the adoption of "clean" techniques by the ocean trace-element community. With the hard work of adopting clean techniques came the reward of "oceanographically consistent" trace-element data. E. Boyle and J. Edmond of MIT (Cambridge, MA), the first to use this term, pointed out that after all, trace-element vertical distributions did not vary randomly but instead had smooth profiles that related well to major hydrographic variables.

Soon the mysteries of various other trace-element distributions were solved and it was no longer fashionable to cite "exploding fecal pellets" as the cause for sudden increases in mid-watercolumn concentrations. Because iron is such a common element (fourth most abundant in earth's crust, 5.6\%) (Taylor, 1964) and because of human's extensive use of iron, contamination problems were and are especially severe. Nevertheless, when good iron data finally began to become available, it was quickly determined that Hart was correct; as expected, iron was indeed much more available inshore than offshore not only for California and Alaska but in the Antarctic as well (Martin et al., 1989, 1990).

In view of the high loads of iron-rich sediments near shore, the confirmation of large values for dissolved and particulate iron in coastal waters was expected. What was really surprising was how low the offshore quantities of Fe turned out to be. 


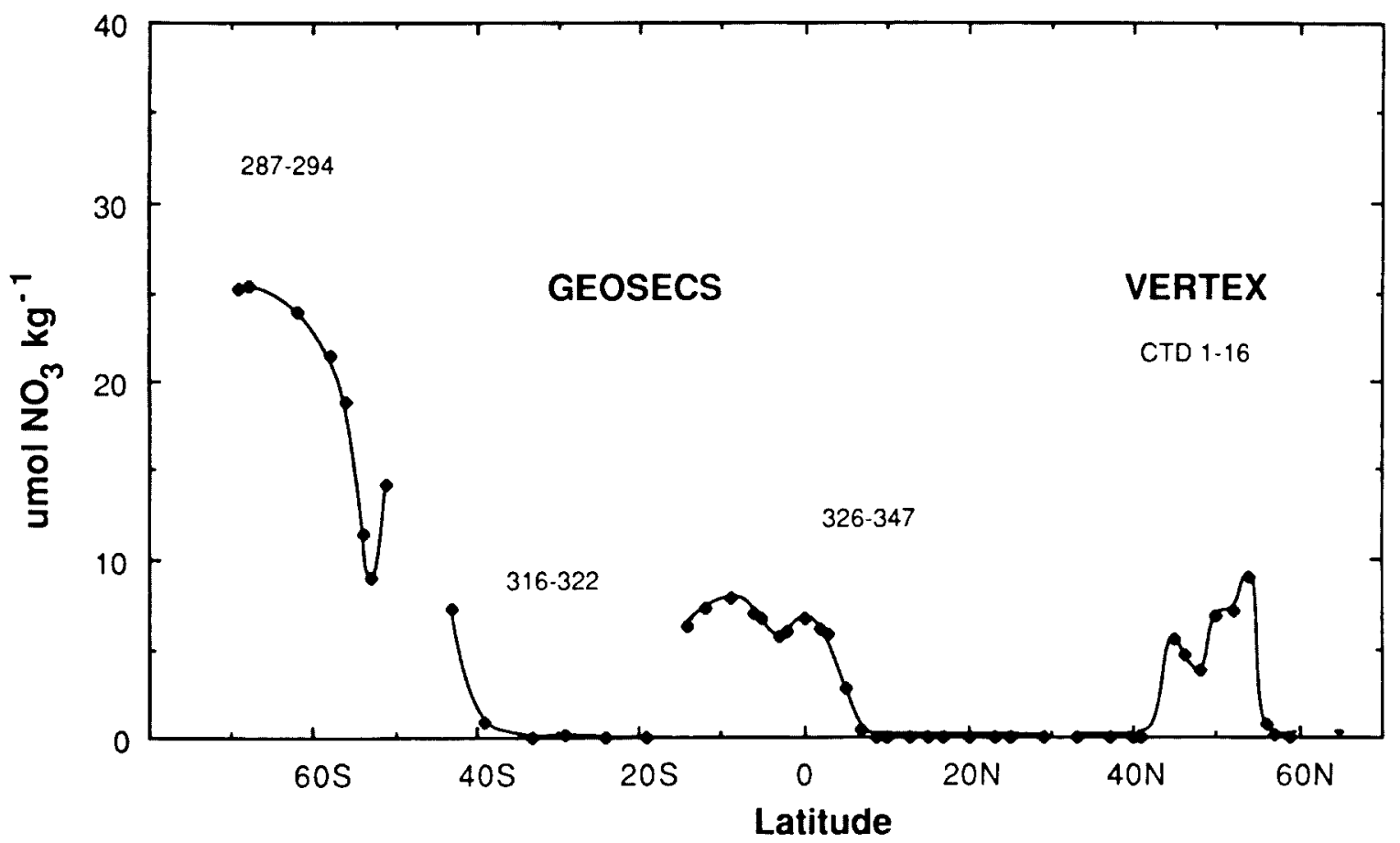

Fig. 1: Surface nitrate concentrations versus latitude in the eastern Pacific (from Martin et al., 1989).

For example, the Fe concentration for offshore Drake Passage surface water is on the order of $0.16 \mathrm{nmol} \mathrm{kg}^{-1}$ (Martin et al., 1990). Assuming that the phytoplankton are nitrate users and have an iron requirement of $15 \mu \mathrm{mol} \mathrm{Fe} / \mathrm{mol} \mathrm{C}$ (Morel et al. 1991, this issue), this would be enough Fe to produce $\sim 10 \mu$ mols of phytoplankton C. Along with the $\mathrm{Fe}$ there was $24.8 \mu \mathrm{mol} \mathrm{NO}_{3} \mathrm{~kg}^{-1}$; i.e., assuming the Redfield ratio of $6.6 \mathrm{C}: 1 \mathrm{~N}$, enough $\mathrm{N}$ to support the production of $160 \mu$ mols of $\mathrm{C}$. Thus, on the basis of seawater $\mathrm{Fe}$ abundance, this means that $<10 \%$ of the $\mathrm{NO}_{3}$ would be used by the phytoplankton before the depletion of available Fe and the cessation of growth.

These observations and those in the Gulf of Alaska (Martin et al., 1989) led us to the disturbing conclusion that open-ocean water is basically infertile. Waters, rich in major nutrients, which are mixed upward into the photic zone, have scarcely any $\mathrm{Fe}$, and in order to support maximal utilization of major nutrients, supplemental Fe must be made available from other sources. Miller and other members of the Subarctic Pacific Ecosystem Research (SUPER) group (see Miller et al., 1991. this issue) were quick to point out that relatively high primary productivity rates are regularly measured in the Gulf of Alaska. They emphasize that one of the highest ever reported was the rate we measured $\left(>1 \mathrm{~g} \mathrm{C} \mathrm{m}^{-2} \mathrm{day}^{-1}\right)$ at Ocean Station Papa (Martin et al., 1989). They have convinced us that there is indeed a small-celled phytoplankton community that does very well with minute quantities of Fe. Its economy is fueled by ammonia, not nitrate, and the population is kept in check by the grazing of microzooplankton.
On the other hand, there are rarer larger diatoms that we believe are doing poorly because of Fe deficiency. In our experiments, when we add nanomole amounts of $\mathrm{Fe}$, these diatoms bloom and quickly remove the superfluous major nutrients, including nitrate. We specifically mention $\mathrm{NO}_{3}$ because $\mathrm{Fe}$ is required for the synthesis of the enzyme nitrate reductase. We believe that similar situations exist in the other major nutrientrich waters, such as the equatorial Pacific and southern ocean. This is our variation of the theme described as the SUPER synthesis (Miller et al., 1991, this issue) and the ecumenical hypothesis of Morel et al. (1991, this issue).

\section{Atmospheric Input}

This leads to a second disturbing conclusion. For open ocean upwelling regions far removed from Fe-rich continental margins, the only way phytoplankton can obtain $\mathrm{Fe}$ is via long-range wind-blown transport and fallout of Fe-rich atmospheric dust originally derived from terrestrial arid regions (Duce, 1986; Donaghay et al., 1991, this issue). Biologists trying to understand phytoplankton production usually think about concentrations and supply rates of major nutrients, available light levels, and cell removal via zooplankton grazing. If our current understanding is correct, biologists must also concern themselves with the amounts of dust falling out on these surface waters. New productivity is not only dependent on the nitrate mixing up into surface waters but also on the iron falling out on them.

The recent knowledge gained about oceanic $\mathrm{Fe}$ distributions and sources provides very strong in-
... the disturbing

conclusion that open-

ocean water is

basically infertile. 
doubling $\mathrm{d}^{-1}$

$\begin{array}{llllllllllll}0 & 0.2 & 0.4 & 0.6 & 0.8 & 1 & 1.2 & 1.4 & 1.6 & 1.8 & 2 & 2.2\end{array}$

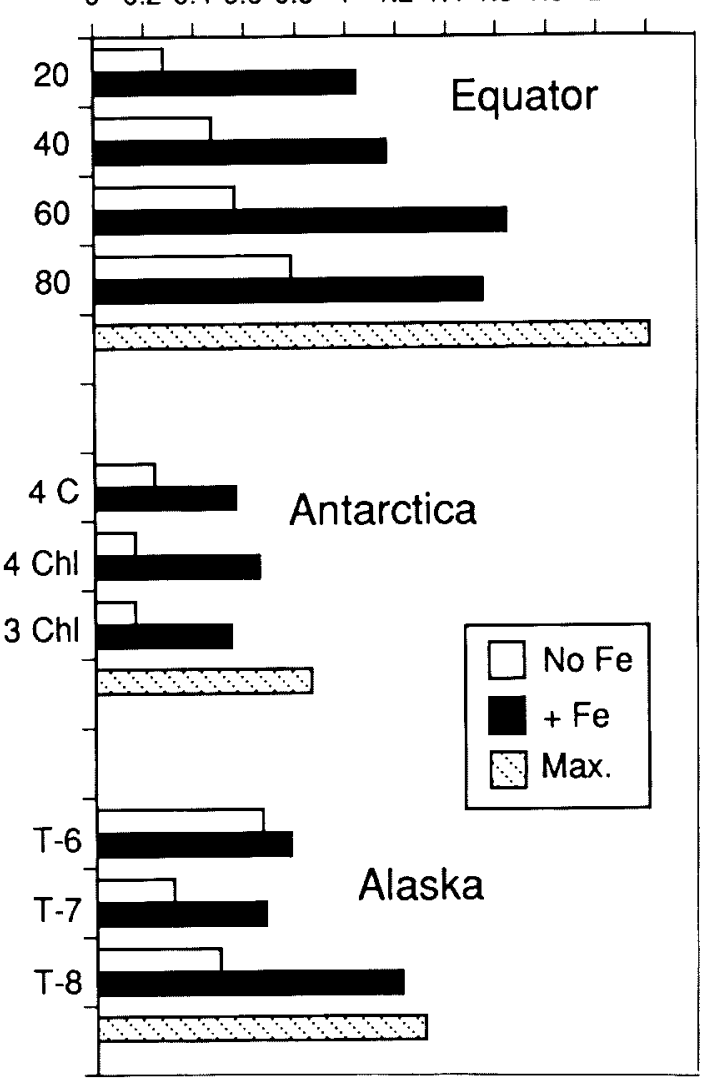

Fig. 2: Comparisons of the rates at which phytoplankton double each day with and without added iron. Theoretical maxima for various temperatures are also shown (from Martin et al., 1991).

direct evidence supporting the iron-as-limitingnutrient hypothesis. Excess nutrients do not occur in Fe-rich coastal waters. For example, normal nutrient depletion occurs as the Alaska continen... present-day

southern-ocean

phytoplankton are not receiving essential iron $\ldots$ and relatively little $\mathrm{CO}_{2}$ is being removed from the atmosphere. sults were similar to those obtained in the Gulf of Alaska and Antarctic (see Fig. 2).

\section{Glacial-Interglacial $\mathrm{CO}_{2}$ Change}

As mentioned above, present-day atmospheric dust loads in the Antarctic are the lowest in the world (Prospero, 1981). However, this was not always the case. The many dune fields (Sarnthein, 1978) active during the last glacial maximum $(18,000$ years ago $)$ indicate that tropical arid areas were 5 times larger, wind speeds 1.3-1.6 times higher, and atmospheric dust loads 10-20 times greater (Petit et al., 1981). Furthermore, ice-core data (De Angelis et al., 1987) show that large amounts of this dust were reaching the Antarctic; i.e., about 50 times as much windborne $\mathrm{Fe}$ was reaching the Antarctic during the last ice age than is today.

When these data are compared with glacialinterglacial $\mathrm{CO}_{2}$ data (Barnola et al., 1987), a striking inverse relationship is observed (Fig. 3). This leads to the hypothesis (Martin, 1990) that southern ocean phytoplankton received essential iron during the glacials from increased atmospheric dust input; the phytoplankton bloomed, the "biological pump" turned on, and $\mathrm{CO}_{2}$ was withdrawn from the atmosphere. In contrast, present-day southern-ocean phytoplankton are not receiving essential iron, the biological pump is turned off, and relatively little $\mathrm{CO}_{2}$ is being removed from the atmosphere.

\section{Iron-Enrichment Experiments}

How much Fe would be required to turn on the biological pump? Back-of-the-envelope calculations suggest that the number is surprisingly small, on the order of a few hundred thousand tons. This observation indicates that it is at least feasible to think about using iron fertilization to stimulate phytoplankton growth, which might turn on the biological pump and in turn promote the removal of the greenhouse gas $\mathrm{CO}_{2}$ from the

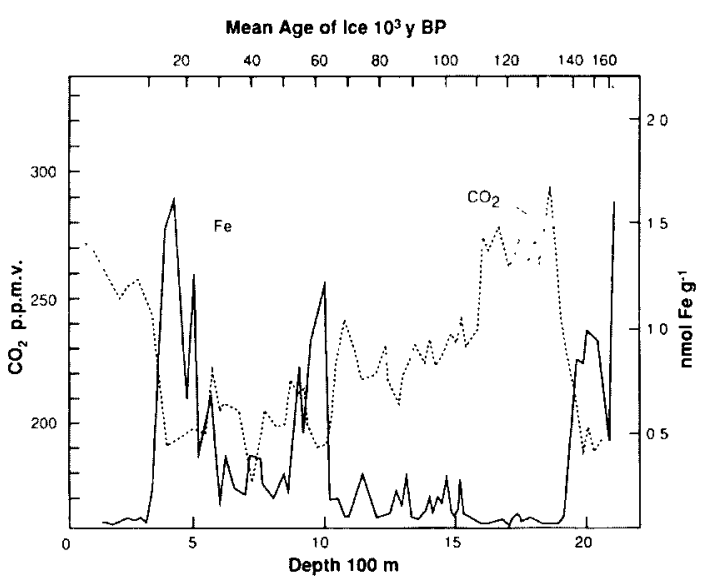

Fig. 3: Iron and carbon dioxide versus age in Vostok ice core. Figure from Martin et al. (1989) based on original data of De Angelis et al. (1987) and Barnola et al. (1987). 
atmosphere. Just thinking about this possibility has led to a variety of reactions ranging from political cartoons, cries of ecological disaster, National Research Council workshops, an American Society of Limnology and Oceanography (ASLO) symposium (Lloyd, 1991), and serious modeling attempts. The model of Peng and Broecker (1991) indicates that even if $\mathrm{Fe}$ fertilization did turn on the pump, little $\mathrm{CO}_{2}$ would be removed from the atmosphere. On the other hand, the model results of Joos et al. (1991) indicate that Fe fertilization could have a significant effect. Their model indicates a $90-$ ppm reduction in atmospheric $\mathrm{CO}_{2}$; this represents $60 \%$ of the increase over the next 100 years provided that input rates remain constant. In commenting on the two models, Sarmiento (1991) agrees ". . . with Broecker that practical application is unlikely." However, he goes on to say that he does ". . . not feel comfortable arguing that models give us clear evidence that iron fertilization would not have a significant impact on atmospheric $\mathrm{CO}_{2}$. If the impact were 9 rather than $90 \mathrm{ppm}$, or 5 rather than $50 \mathrm{ppm}$, I would agree with Broecker's comment in this regards, but such is not the case."

Both models indicate that if fertilization were used, it would have to be carried out until fossilfuel emissions were drastically reduced (hundreds of years); thus, it represents a Faustian bargain at best. Others point to the potential for ecological disaster by massive manipulation of the ocean. All of these concerns are certainly valid. A symposium (ASLO, 1991) dealing with these issues led to the adoption of a resolution that ". . . . urges all governments to regard the role of iron in marine productivity as an area for further research and not to consider iron fertilization as a policy option that significantly changes the need to reduce emissions of carbon dioxide." The participants found the collected evidence for iron limitation in nutrient-rich seas to be compelling. and they recommended that the hypothesis be examined in depth and that a modestly scaled ironenrichment experiment be designed for a highnutrient region of the open sea. With the performance of such experiments we will be able to better understand the exact nature of the relationship between iron, Liebig's law, the ocean, and perhaps the greenhouse as well.

\section{Acknowledgements}

The Moss Landing Marine Laboratories iron work is supported by grants from the ONR Ocean Chemistry Program (N 000 14-84-C-0619), the NSF Marine Chemistry Program (OCE 8813565), and the Biology and Medicine Section of NSF Polar Programs (DPP 8716460).

\section{References}

ASLO, 1991: What controls phytoplankton production in nutrient-rich areas of the open sea? Symposium. American
Society of Limnology and Oceanography Symposium. February 22-24, 1991, San Marcos, California.

Barnola, J.M., D. Raynaud. Y.S. Korotkevich and C. Lorius. 1987: Vostok ice core provides 160,000-year record of atmospheric CO2. Nature, 329, 408-414.

De Angelis, M., N.I. Barkov and V.N. Petrov, 1987: Aerosol concentrations over the last climatic cycle (160 kyr) from an Antarctic ice core. Nature, 325, 318-321.

Donaghay, P.L., P.S. Liss, R.A. Duce, D.R. Kester, A.K. Hanson, T. Villareal, N. Tindale and D.J. Gifford, 1991: The role of episodic atmospheric nutrient inputs in the chemical and biological dynamics of oceanic ecosystems. Oceanography: 4, 62-70.

Duce, R.A., 1986: The impact of atmospheric nitrogen, phosphorus, and iron species on marine biological productivity. In: The Role of Air-sea Exchange in Geochemical Cycling, P. Buat-Menard, ed.. D. Reidel Publishing Company, Dordrecht, 497-529.

El-Sayed, S.Z., 1988: Productivity of the Southern Ocean: a closer look. Comp. Biochem. Physiol., 90B, 489-498.

Hart, T.J., 1934: On the phytoplankton of the south-west Atlantic and the Bellingshausen Sea, 1929-31. Discovery Reports, 8, 1-268.

1942: Phytoplankton periodicity in Antarctic surface waters. Discovery Reports, 21, 261-356.

Joos, F., J.L. Sarmiento and U. Sigenthaler, 1991: Estimates of the effect of Southern Ocean iron fertilization on atmospheric $\mathrm{CO} 2$ concentrations. Nature. 349. $772-$ 775 .

Lloyd, P., 1991: Iron determinations. Nature, 350, 19

Martin, J.H., R.M. Gordon, S. Fitzwater and W.W. Broenkow. 1989: VERTEX: phytoplankton/iron studies in the Gulf of Alaska. Deep-Sea Res.. 36, 649-680.

1990: Glacial-Interglacial $\mathrm{CO}_{2}$ change: the iron hypothesis. Paleoceanography, 5, 1-13.

, R.M. Gordon and S.E. Fitzwater, 1990: Iron in Antarctic waters. Nature, $345,156-158$.

, R.M. Gordon and S.E. Fitzwater, 1991: The case for iron. In: What Controls Phytoplankton Production in Nutrient-Rich Areas of the Open Sea.' S. Chisholm and F. Morel, eds., Limnol. Oceanogr., 36.

Miller, C.B., B.W. Frost, B. Booth. P.A. Wheeler, M.R. Landry and N. Welschmeyer. 1991: Ecological processes in the subarctic Pacific: iron-limitation cannot be the whole story. Oceanography, 4, 71-78.

Morel, F.M.M., J.G. Rueter and N.M. Price, 1991: Iron nutrition of phytoplankton and its possible importance in the ecology of ocean regions with high nutrient and low biomass. Oceanography: 4, 56-61.

Moulton, F.R. (ed.), 1942: Liebig and after Liebig. A.ASS Pub. No. 16, Washington, DC.

Odum, E.P., 1971: Fundamentals of Ecology: 3rd. Ed. W.B. Saunders Co., Philadelphia, $574 \mathrm{p}$.

Peng, T.-H. and W.S. Broecker, 1991: Dynamical limitations on the Antarctic iron fertilization. Nature. 349, 227229.

Petit, J-R., M. Briat and A. Royer, 1981: Ice age aerosol content from East Antarctic ice core samples and past wind strength. Nature, 293, 391-394.

Prospero, J.M., 1981: Eolian transport to the world ocean. In: The Sea, Vol. 7. C. Emiliani, ed., Wiley, New York, 801-874.

Sarmiento, J.L., 1991: Slowing the buildup of fossil $\mathrm{CO}_{2}$ in the atmosphere by iron fertilization: a comment. Global Biogeochem. Cycles, 5, 1-2.

Sarnthein, M., 1978: Sand deserts during glacial maximum and climatic optimum. Nature, 272,43-46.

Taylor, S.R., 1964: Abundance of chemical elements in the continental crust: a new table. Geochim. Cosmochim. Acta, 28, 1273-1285.

Uematsu, M.. 1987: Study of the continental material transported through the atmosphere to the ocean. J. Ocean ogr. Soc., Japan, 43. 395-401.
... a modestly scaled

iron-enrichment

experiment be

designed for a high-

nutrient region of the

open sea. 